\title{
The Effect of Energy Balance on Ovarian Activity in a Herd of Norwegian Cattle
}

\author{
By K. Ljøkjel ${ }^{l}$, G. Klemetsdal ${ }^{1}$, E. Prestløkken ${ }^{1}$ and E. Ropstad ${ }^{2}$ \\ ${ }^{1}$ Department of Animal Science, Agricultural University of Norway, Ås, and ${ }^{2}$ Department of Reproduction and \\ Forensic Medicine, Norwegian College of Veterinary Medicine, Oslo, Norway.
}

\begin{abstract}
Ljøkjel K., G. Klemetsdal, E. Prestløkken and E. Ropstad: The effect of energy balance on ovarian activity in a herd of Norwegian cattle. Acta vet. scand. 1995, 36, 533-542. - The study involved 34 primiparous cows fed ad libitum grass silage and fixed amounts of concentrate per cow and stage of lactation. It revealed that number of days from calving to maximum progesterone concentration in first luteal phase was negatively related to $(\mathrm{p}<0.05)$ energy balance summarized over weeks 3-12 post-partum. One standard deviation improvement of the summarized energy balance relative to the mean reduced the length of the anovulatory period by 12 days. Similarly, an improved energy balance enhanced progesterone secretion during the oestrus cycle and early pregnancy, as measured by 3 variables; 1) maximum progesterone concentration in first luteal phase, 2) cumulative progesterone secretion bounded by the maximum concentrations in first and in third luteal phase and 3) cumulative progesterone secretion in the first month of pregnancy. All results were supported by the estimated regression coefficients of the 4 ovarian activity variables on summarized non-estrified fatty acids and acetoacetate variables.
\end{abstract}

anovulatory period; blood metabolites; dairy cattle; feeding variables; milk progesterone; post-partum.

\section{Introduction}

In primiparous cows commonly used fertility variables as days open and calving interval are normally made up of an anovulatory and an ovulatory period. Therefore, the length of the anovulatory period affects the 2 fertility variables. To determine its length rectal ovarian palpation or transrectal ultrasonography is normally used (Marion \& Gier 1968, Whitmore et al. 1974, Stevenson \& Britt 1979, Savio et al. 1990, Lucy et al. 1992). In the present paper, the anovulatory period is defined from milk progesterone assay, as the number of days from calving to the maximum milk progesterone concentration level in first luteal phase. Follicular growth and development has been shown to vary widely after parturition, ranging from formation of primary follicles (follicles $<10 \mathrm{~mm}$ ) 10 to 15 days post-partum (Marion \& Gier 1968), to complete absence of primary follicles after several weeks (Stevenson \& Britt 1979). Butler \& Smith (1989), Roche et al. (1992) and Savio et al. (1990) stated that milk yield, energy- and protein balance, age, season, number of lactations and breed effect are among the most important causes of variable length of the interval from parturition to first ovulation in dairy cattle. Marion \& Gier (1968) and Whitmore et al. (1974) reported prolonged interval from calving to first ovulation for highyielding cows compared to cows with lower milk production. The opposite result has been found in other studies (Staples et al. 1990, Stevenson \& Britt 1979). Harrison et al. (1989) 
found no differences in resumption of ovarian activity between cows with high and low milk yield.

Ovarian activity results are more consistent when the energy balance is taken into account. Negative energy balance is generally associated with delayed post-partum ovulation (Butler et al. 1981, Canfield \& Butler 1990), and with lower progesterone secretion during the first to third luteal phases (Spicer et al. 1990, Villa-Godoy et al. 1988). The aim of this study was to examine the effect of energy balance on ovarian activity in primiparous cows as determined by variables derived from 2 weekly measurement of milk progesterone.

\section{Materials and methods}

A total of 34 primiparous cows were distributed over 2 selection lines ( $\mathrm{n}=17$ per line), one selected for high (high-line) and one for low milk production (low-line). The approximate difference in milk production between lines was $1200 \mathrm{~kg}$ milk per year.

Concentrate was fed at a fixed level of 6 and 8 $\mathrm{kg}$ per day during weeks 2-8, and 5 and $7 \mathrm{~kg}$ per day during weeks 9-12 of lactation for low- and high-line cows, respectively. Additionally, cows within lines were randomly allocated one of 2 different concentrate mixtures with equal content of feed units milk (FEm) and amino acids absorbed in the small intestine (AAT). FEm was calculated according to Ekern et al. (1991). AAT was derived according to the method of Madsen et al. (1995). In concentrate mixture 1, the AAT level was increased by hydrothermal treatment ("The annular gap expander", A. $\mathrm{Kahl}, 130^{\circ} \mathrm{C}$ ) of barley and oats prior to mixing. In concentrate mixture 2, the AAT level was enhanced by use of lignosulfate-treated soybean meal (SoyPass) as described by Nakamura et al. (1992). In addition to concentrate, cows were fed grass silage ad libitum and $1 \mathrm{~kg}$ straw per day. Silage intake was recorded weekly as the average daily intake over a 4 day period. Samples of silage and concentrate were collected weekly over 4 week periods. Silage samples were frozen at $-18^{\circ} \mathrm{C}$. In order to calculate FEm and AAT, both feedstuffs were analysed for main nutrients, and coefficients of digestibility were found with 3 sheep fed at maintenance. Protein degradability and intestinal digestibility were determined according to Madsen et al. (1995). Milk yield was recorded twice weekly, and the percentages of protein, fat and lactose were determined in 1 sample each week. Live weight was recorded twice the first week after calving and then once in succeeding weeks until week 12 of lactation. Blood samples were collected weekly (before morning feeding), and plasma samples were stored at $-80^{\circ} \mathrm{C}$ until subsequent analysis for acetoacatate, non esterified fatty acids (NEFA) and urea on the Encore ${ }^{\mathrm{TM}}$ (Baker Instruments) autoanalyser. Acetoacetate was determined using sodiumnitropruside as described by Gau (1987). NEFA concentration was measured by enzymatic colorimetric procedure (Mulder et al. 1983) (Reagents from Wako Chemicals), and urea was determined after Kaplan (1987) (Regents from Beckman DriSTAT USA).

Milk samples were collected twice weekly, and were assayed for progesterone content. Sampling started in lactation week 3 i.e. 16 to 21 days after parturition, and varied in length among cows as it was continued until the animals went on pasture in May. The progesterone concentration was determined by radioimmunoassay, according to the method of Andresen \& Onstad (1979). The specificity of the antiserum has been described by Baishya et al. (1980). Interassay coefficient of variation was $<13 \%$ for control samples with progesterone concentration ranging from $3.2-35 \mathrm{ng} / \mathrm{ml}$. The intraassay coefficients of variation of the same samples were $<5 \%$, and the sensitivity of the assay was $0.2 \mathrm{ng} / \mathrm{ml}$. 
Four ovarian activity variables were derived from the progesterone data and additional oestrus detection and insemination information; 1) number of days from calving to maximum progesterone level for the luteal phase of the first detected cycle with concentration $>5 \mathrm{ng} / \mathrm{ml}$ (first luteal phase), 2) maximum progesterone concentration in first luteal phase, 3) cumulative progesterone secretion between the maximum concentrations in first and in third luteal phase and 4) cumulative progesterone secretion in the first month of pregnancy. All cows without measurable post-partum progesterone secretion were assigned a value of zero for the second and third variable.

Daily energy- and AAT-balance on a weekly basis were calculated as FEm and AAT values of consumed roughage and concentrate, less the corresponding requirements for milk production and maintenance. Requirement for growth was not taken into account. In addition, total dry matter intake and concentrate to silage ratio, on a dry matter basis, were calculated.

Weekly live weight observations were restricted to the first 12 weeks of lactation. This motivated a data reduction which was carried out for all explanatory variables by summarizing the data over weeks 3-12 post-partum. Any missing values (on average $25 \%$ of all values) were replaced by predicted values. The predicted values stemmed from a mixed model which included a fixed main effect made up by genetic line, concentrate type and week of lactation, and a second random animal effect. The mixed model procedure of SAS Institute Inc. (1992) was used. Cows were assumed unrelated and all observations were treated as uncorrelated in analyses.

In order to interpret the correlation structure among the summarized feeding variables and to estimate factor scores for subsequent linear regression analyses, a factor analysis (SAS Institute Inc. 1987) was carried out. Generally, the factor analysis is based on the factor model in which the observations are postulated linearly dependent upon the matrix product of unobservable factors and their factor loadings in addition to an error term (e.g. Johnson \& Wichern 1982). By introducing additional assumptions into the model, the factor loadings were estimated by use of the principal component method on basis of standardised variables. By applying an orthogonal transformation, i.e. a rotation, the varimax criterion was made as large as possible. To determine the appropriate number of factors, the proportion of the total sample variance due to the $j$-th factor was used as a criterion. It is, in fact, calculated by summarizing the squared loadings of the factor and dividing by the total number of variables. Finally, the independent factor scores, with mean zero and variance one, were estimated by treating the estimated rotated factor loadings as true values.

Associations between summarized ovarian activity variables and summarized variables of feeding, their factor scores, and summarized blood metabolites were examined by use of a general linear model procedure (SAS Institute Inc. 1987) and forward selection of variables. The genetic lines were not included in these final statistical analyses, and thus they only ensured a broadened scope of the experiment.

\section{Results}

Descriptive statistics of ovarian activity, weekly and summarized feeding and blood metabolite variables utilized in analyses, and in addition milk yield, are given in Table 1 .

Number of days from calving to maximum progesterone concentration in first luteal phase On average, number of days from calving to maximum progesterone level in first luteal phase was 70.5 days post-partum (Table 1). Simple regression models revealed significant 
$\mathrm{T}$ a b l e 1 . Total number of observations and descriptive statistics of ovarian activity and feeding variables in addition to blood metabolites.

\begin{tabular}{|c|c|c|c|c|c|}
\hline Ovarian activity variables & $\mathrm{N}$ & Mean & SD & Maximum & Minimum \\
\hline $\begin{array}{l}\text { Number of days from calving to the maximum } \\
\text { progesterone level in first luteal phase }\end{array}$ & 34 & 70.5 & 36.8 & 150.0 & 16.0 \\
\hline $\begin{array}{l}\text { Maximum concentration of progesterone in } \\
\text { first luteal phase, } \mathrm{ng} / \mathrm{ml}^{1)}\end{array}$ & 34 & 9.3 & 6.9 & 23.8 & 0.0 \\
\hline $\begin{array}{l}\text { The cumulative progesterone secretion } \\
\text { bounded by the maximum level in first and } \\
\text { in third luteal phase, } \mathrm{ng} / \mathrm{ml}^{1)}\end{array}$ & 25 & 217.7 & 127.5 & 425.0 & 0.0 \\
\hline $\begin{array}{l}\text { The cumulative progesterone secretion in } \\
\text { the first month of pregnancy, ng/ml }\end{array}$ & 15 & 493.5 & 189.5 & 754.4 & 93.9 \\
\hline \multicolumn{6}{|l|}{ Feeding variables } \\
\hline Milk yield, kg/day & 293 & 21.8 & 4.6 & 33.1 & 10.4 \\
\hline Energy balance, FEm/day & 246 & -1.6 & 1.5 & 2.2 & -5.6 \\
\hline $\mathrm{AAT}^{2)}$-balance, $\mathrm{g}$ /day & 246 & -101.0 & 166.5 & 329.0 & -527.0 \\
\hline $\begin{array}{l}\text { Concentrate to silage ratio, } \% \text { dry matter } \\
\text { of total ration }\end{array}$ & 246 & 42.6 & 5.6 & 64.4 & 30.3 \\
\hline Dry matter intake, $\mathrm{kg} /$ day & 246 & 13.8 & 1.5 & 17.2 & 9.5 \\
\hline Summarized energy balance, FEm, weeks 3-12 & 34 & -98.6 & 81.8 & 65.2 & -265.7 \\
\hline Summarized AAT-balance, g, weeks 3-12 & 34 & -6236.9 & 8914.4 & 12575.7 & -24755.3 \\
\hline $\begin{array}{l}\text { Summarized concentrate to silage ratio, } \\
\text { weeks } 3-12^{3)}\end{array}$ & 34 & 2678.0 & 273.8 & 3173.9 & 2281.0 \\
\hline Summarized dry matter intake, $\mathrm{kg}$, weeks 3-12 & 34 & 874.7 & 77.9 & 1027.0 & 721.2 \\
\hline \multicolumn{6}{|l|}{ Blood metabolites } \\
\hline Acetoacetate, $\mu \mathrm{mol} / 1$ & 237 & 95.2 & 142.5 & 1109.2 & 11.1 \\
\hline $\mathrm{NEFA}^{4)}, \mathrm{mmol} / \mathrm{l}$ & 226 & 0.5 & 0.2 & 1.4 & 0.2 \\
\hline Urea, $\mathrm{mmol} / 1$ & 251 & 5.4 & 1.2 & 8.5 & 2.2 \\
\hline $\begin{array}{l}\text { Summarized acetoacetate, cumulative } \mu \mathrm{mol} / 1 \text {, } \\
\text { weeks } 3-12\end{array}$ & 34 & 5939.3 & 4969.5 & 21657.0 & 1651.6 \\
\hline $\begin{array}{l}\text { Summarized NEFA, cumulative } \mathrm{mmol} / \mathrm{l} \text {, } \\
\text { weeks } 3-12\end{array}$ & 34 & 30.3 & 9.4 & 57.3 & 18.7 \\
\hline $\begin{array}{l}\text { Summarized urea, cumulative } \mathrm{mmol} / \mathrm{l} \text {, } \\
\text { weeks } 3-12\end{array}$ & 34 & 339.0 & 43.1 & 421.7 & 253.3 \\
\hline
\end{tabular}

\footnotetext{
1) Cows without observed progesterone secretion were given a value of zero.

2) Amino acids absorbed in the small intestine.

3) Relative variable indicating individual variation in roughage intake.

4) Non-estrified fatty acids.
}

$(p<0.05)$ effects of both summarized energy balance and summarized dry matter intake on the former variable (Table 2). Summarized energy balance and summarized dry matter intake also had large positive loadings on the first and the third factor, respectively, based on the factor analysis of the feeding variables (Table 3). The summarized AAT-balance had large positive loadings on the first factor (Table 3), confirming the similarity in derivation of the energyand AAT-balance. Hence, the first factor may be labelled an energy balance factor. Similarly, the third factor might be called a dry matter intake factor or a production factor, while the sec- 
$\mathrm{T}$ a b 1 e 2. Least-squares means regression ( $($ ) of number of days from calving to maximum progesterone level in first luteal phase on associated feeding and 3 blood metabolite variables in 9 analyses. The regression coefficients' level of significance $(\mathrm{P})$ and the models' coefficient of determination $\left(\mathrm{R}^{2}\right)$ are also included.

\begin{tabular}{|c|c|c|c|c|}
\hline Analysis & Variable & B & $P$ & $\mathrm{R}^{2}$ \\
\hline 1 & Summarized energy balance & -0.206 & 0.017 & 0.165 \\
\hline 2 & Summarized concentrate to silage ratio & 0.032 & 0.233 & 0.044 \\
\hline 3 & Summarized dry matter intake & 0.215 & 0.018 & 0.163 \\
\hline 4 & Concentrate type & - & 0.728 & 0.003 \\
\hline \multirow[t]{2}{*}{5} & Summarized energy balance & -0.148 & 0.098 & 0.230 \\
\hline & Summarized dry matter intake & 0.152 & 0.105 & \\
\hline \multirow[t]{2}{*}{6} & Factor scores for factor $1^{1)}$ & -14.240 & 0.037 & 0.234 \\
\hline & Factor scores for factor $3^{2)}$ & 14.651 & 0.033 & \\
\hline 7 & Summarized acetoacetate & 0.002 & 0.045 & 0.119 \\
\hline 8 & Summarized NEFA ${ }^{3)}$ & 1.732 & 0.025 & 0.156 \\
\hline 9 & Summarized urea & -0.469 & 0.004 & 0.237 \\
\hline
\end{tabular}

1) Interpreted as an energy balance factor.

2) Interpreted as a production factor.

3) Non-estrified fatty acids.

ond factor loaded extensively on the summarized concentrate to silage ratio. Number of days from calving to maximum progesterone concentration in first luteal phase was significantly $(\mathrm{p}<0.05)$ affected by factor scores derived from factors one and three (Table 2). This supported the findings of the simple regression analyses. In contrast, multiple regression analysis on basis of the original variables resulted in less insight as neither regression coefficients were significantly $(\mathrm{p}<0.05)$ different from zero (Table 2). Irrespective of analysis, number of days from calving to maximum progesterone concentration in first luteal phase regressed nega- tively on summarized energy balance and positively on summarized dry matter intake. Hence, an improved energy balance shortened the number of days from calving to maximum progesterone concentration in first luteal phase, while enhanced dry matter intake, possibly as a result of increased milk production, lengthened the same interval.

The regression coefficient of number of days from calving to maximum progesterone concentration in first luteal phase was significant $(\mathrm{p}<0.05)$ and positively related to the summarized blood metabolites of acetoacetate and NEFA (Table 2). This indicates that increased

$\mathrm{T}$ a b l e 3. Varimax rotated principal component estimates of factor loadings for feeding variables on basis of a 3 factor model. The number of factors was chosen according to the magnitude of the cumulative proportion of the explained total sample variance.

\begin{tabular}{lccc}
\hline Feeding variable & Factor 1 & Factor 2 & Factor 3 \\
\hline Summarized energy balance & 0.97 & -0.19 & -0.17 \\
Summarized AAT ${ }^{1)}$-balance & 0.98 & -0.14 & -0.19 \\
Summarized dry matter intake & -0.21 & 0.17 & 0.96 \\
Summarized concentrate to silage ratio & -0.19 & 0.97 & 0.17 \\
\hline Cumulative proportion of total sample variance & 0.49 & 0.75 & 1.00 \\
\hline
\end{tabular}

1) Amino acids absorbed in the small intestine. 
$\mathrm{T}$ a b l e 4. Least-squares means regression ( $(\beta)$ of maximum concentration of progesterone secretion in first luteal phase on associated feeding and 3 blood metabolite variables in 8 analyses. The regression coefficients' level of significance $(\mathrm{P})$ and the models' coefficient of determination $\left(\mathrm{R}^{2}\right)$ are also included.

\begin{tabular}{llrcc}
\hline Analysis & Variable & $\beta$ & $\mathrm{P}$ & $\mathrm{R}^{2}$ \\
\hline 1 & Summarized energy balance & 0.047 & 0.012 & 0.316 \\
2 & Summarized concentrate to silage ratio & -0.008 & 0.072 & 0.100 \\
3 & Summarized dry matter intake & -0.024 & 0.127 & 0.073 \\
4 & Concentrate type $_{5}$ & - & 0.725 & 0.004 \\
5 & Factor scores for factor 1 1) & 3.590 & 0.001 & 0.270 \\
6 & Summarized acetoacetate & 0.000 & 0.065 & 0.117 \\
7 & Summarized NEFA 2) & -0.329 & 0.008 & 0.206 \\
8 & Summarized urea & 0.049 & 0.078 & 0.096 \\
\hline
\end{tabular}

1) Interpreted as an energy balance factor.

2) Non-estrified fatty acids.

concentration of acetoacetate and NEFA resulted in a prolonged anovulatory period, while the anovulatory interval was shortened from higher concentration of blood urea (Table 2).

\section{Progesterone secretion during oestrus cycle and early pregnancy}

Three variables were used to describe the progesterone secretion during oestrus cycle and early pregnancy. The variables were; maximum level of progesterone secretion in first luteal phase, cumulative progesterone secretion bounded by the maximum concentrations in first and in third luteal phase and progesterone secretion in the first month of the pregnancy. The three variables regressed positively and significant $(\mathrm{p}<0.05)$ on the summarized energy balance as shown in Tables 4, 5 and 6. Furthermore, positive regression of the corresponding three variables on the factor scores of summarized energy balance were estimated (Tables 4, 5 and 6 , respectively). These results imply that progesterone secretion was enhanced from an improved energy balance.

$\mathrm{T}$ a b 1 e 5 . Least-squares means regression ( $($ ) of cumulative progesterone secretion bounded by the maximum level in first and in third luteal phase on associated feeding and 3 blood metabolite variables in 8 analyses. The regression coefficients' level of significance $(\mathrm{P})$ and the models' coefficient of determination $\left(\mathrm{R}^{2}\right)$ are also included.

\begin{tabular}{llrrr}
\hline Analysis & Variable & $\beta$ & $P$ & $R^{2}$ \\
\hline 1 & Summarized energy balance & 0.704 & 0.017 & 0.225 \\
2 & Summarized concentrate to silage ratio & -0.138 & 0.159 & 0.084 \\
3 & Summarized dry matter intake & -0.437 & 0.196 & 0.071 \\
4 & Concentrate type & - & 0.297 & 0.047 \\
5 & Factor scores for factor 1 1) & 48.63 & 0.045 & 0.164 \\
6 & Summarized acetoacetate & -0.010 & 0.006 & 0.287 \\
7 & Summarized NEFA 2) & -5.314 & 0.034 & 0.187 \\
8 & Summarized urea & 0.459 & 0.425 & 0.028 \\
\hline
\end{tabular}

\footnotetext{
1) Interpreted as an energy balance factor.
}

2) Non-estrified fatty acids. 
$\mathrm{T}$ a b 1 e 6. Least-squares means regression (B) of cumulative progesterone secretion during the first month of the pregnancy on associated feeding and 3 blood metabolite variables in 10 analyses. The regression coefficients' level of significance $(\mathrm{P})$ and the models' coefficient of determination $\left(\mathrm{R}^{2}\right)$ are also included.

\begin{tabular}{clrcc}
\hline Analysis & Variable & $\beta$ & $\mathrm{P}$ & $\mathrm{R}^{2}$ \\
\hline 1 & Summarized energy balance & 1.668 & 0.015 & 0.378 \\
2 & Summarized concentrate to silage ratio & -0.236 & 0.198 & 0.123 \\
3 & Summarized dry matter intake & -1.374 & 0.035 & 0.298 \\
4 & Concentrate type & - & 0.835 & 0.003 \\
5 & Summarized energy balance & 1.218 & 0.119 & 0.431 \\
& Summarized dry matter intake & -0.716 & 0.309 & \\
6 & Factor scores for factor 1 1) & 111.832 & 0.074 & 0.389 \\
& Factor scores for factor 3 2) & -62.987 & 0.208 & \\
7 & Factor scores for factor 1 1) & 133.227 & 0.035 & 0.300 \\
8 & Summarized acetoacetate & -0.029 & 0.016 & 0.369 \\
9 & Summarized NEFA 3) & -9.704 & 0.050 & 0.263 \\
10 & Summarized urea & -0.158 & 0.936 & 0.000 \\
\hline
\end{tabular}

1) Interpreted as an energy balance factor.

${ }^{2)}$ Interpreted as a production factor.

3) Non-estrified fatty acids.

Results of Tables 4, 5 and 6 also point out that the progesterone secretion was reduced from increased values of acetoacetate and NEFA as the regression of the three progesterone secretion variables on summarized acetoacetate and NEFA values were generally significant $(\mathrm{P}<0.05)$ and negative. However, one exception existed; the regression of the maximum concentration of progesterone in first luteal phase on summarized acetoacetate values (Table 4).

\section{Discussion}

In this experiment, the minimum average daily energy balance over the lactation period was not reached until after the twentieth week of lactation. Individual variation existed and made the experiment well suited for examining the effect of energy balance on ovarian activity among cows. All four ovarian activity variables derived from milk progesterone concentration were positively related to an improved energy balance. The milk progesterone sampling, how- ever, did not start before the third week of lactation, and first luteal phase may have been misclassified for some animals. The consequence would be reduced variation in the first variable; number of days from calving to maximum progesterone concentration in first luteal phase, and less information in data. On that basis, an effect of energy balance was estimated, and improved sampling and determination of first luteal phase would most likely strengthen the energy balance results. Concerning the variables which depend on the maximum concentration of progesterone in first luteal phase, a misclassification of the first phase may be of some importance as the progesterone concentration is normally higher in the second than in the first luteal phase (Kovacevic et al. 1987, Staples et al. 1990, Stevenson \& Britt 1979, Vesanen et al. 1990). Consequently, the estimated effect would be a mixture of the energy balance and specific characteristics of each luteal phase, and only an improved set up of a new experiment may give better insight. 
Generally, a worsened energy balance increased the number of days from calving to maximum progesterone concentration in first luteal phase, and reduced the progesterone secretion as measured by the maximum concentration of progesterone in first luteal phase. Reduced values of the latter variable are known to affect ovarian activity as it results in a shorter succeeding cycle length (Kovacevic et al. 1987, Staples et al. 1990, Stevenson \& Britt 1979, Vesanen et al. 1990). A worsened energy balance also decreased cumulative progesterone secretion bounded by the maximum concentrations in first and in third luteal phase, and cumulative progesterone secretion during the first month of the pregnancy was affected similarly. Results for the first, second and third variable are supported by the literature. Butler et al. (1981) and Canfield \& Butler (1990) reported an increased length of the anovularory period from a worsened energy balance. Butler et al. (1981) found ovulation and initiation of the first normal luteal phase to occur approximately 10 days after the minimum post-partum energy balance had been reached. Spicer et al. (1990) calculated the area under the progesterone secretion curve and found it to be 1.8-fold greater among cows with positive energy balance than among cows with negative energy balance. Villa-Godoy et al. (1988) observed an increased secretion of progesterone in the second and third luteal phase for animals which had a positive energy balance within nine days post-partum. The relationship between energy balance and ovarian activity was further strengthened by the significant blood metabolite regression coefficients and their direction. In fact, higher concentrations of NEFA and acetoacetate, which both indicate low energy balance, were present in cows with longer anovulatory intervals and in cows with lower secretion of progesterone. Canfield \& Butler (1990) also reported NEFA concentration to affect the number of days to first ovula- tion.

In order to explain the observed effect of energy balance on the anovulatory interval, several theories have been tendered. Canfield \& Butler (1990) suggested that NEFA's provided feedback indicating negative energy balance by penetrating the blood-brain barrier and thereby invoking a response from the central nervous system. Alternatively, Butler \& Smith (1989) proposed that the low insulin secretion levels during negative energy balance suppressed the reproductive axis by the blocking of gonadotrophin releasing hormone $(\mathrm{GnRH})$, and therefore luteinizing hormone $(\mathrm{LH})$, pulsatility. VillaGodoy et al. (1988) discussed the effect of energy balance on the progesterone secretion. They proposed that normal lifespan but reduced function of the second and third corpus luteum stemmed from reduced luteal development or decreased secretory activity per luteal cell, or a combination of these effects.

To illustrate the magnitude of the effect, number of days from calving to maximum progesterone concentration in first luteal phase may be chosen. An improvement of the summarized energy balance with one phenotypic standard deviation corresponding to $82 \mathrm{FEm}$ over weeks 3 - 12 post-partum or $1.3 \mathrm{FEm}$ per day would, by use of the results in Table 3 and analysis 6 , reduce the number of days from calving to maximum progesterone concentration in first luteal phase by 12 days. The results refers to an average negative energy balance situation (- 1.6 FEm per day) and should be interpreted on that ground.

\section{Acknowledgements}

The antiserum used for progesterone analysis was kindly donated by Dr. G.S. Pope. We thank ClaesGøran Fristedt and Ann-Lill Hafne for excellent technical assistance. 


\section{References}

Andresen $\emptyset$, Onstad, $O$ : Brunstkontroll og drektighetskontroll hos ku ved hjelp av progesteronbestemmelse i melk. (Heat and pregnancy control in cows using progesterone values in milk.) Norsk Veterinærtidsskrift 1979, 91, 411-421.

Baishya N, Ball PJ, Leaver JD, Pope GS: Fertility of lactating cows inseminated after treatment with cloprostenol. Br. Vet. J. 1980, 136, 227-239.

Butler WR, Everett RW, Coppock CE: The relationships between energy balance, milk production and ovulation in postpartum Holstein cows. J. Anim. Sci. 1981, 53, 742-748.

Butler WR, Smith RD: Interrelationships between energy balance and postpartum reproductive function in dairy cattle. J. Dairy Sci. 1989, 72, 767783.

Canfield RW, Butler WR: Energy balance and pulsatile LH secretion in early postpartum dairy cattle. Dom. Anim. Endocr. 1990, 7, 323-330.

Ekern A et al.: Nytt system for energivurdering av fôr til drøvtyggere. (A new system for energy evaluation of food for ruminants.) Norsk Landbruksforskning 1991, 5, 273-277.

Gau N: Acetoacetic acid. In: Pesce AJ, Kaplan LA (eds): Methods in Clinical Chemistry. The C.V. Mosby Company, Washington D.C. 1987, 97100.

Harrison RO, Young JW, Freeman AE, Ford SP: Effects of lactational level on reactivation of ovarian function, and interval from parturition to first visual oestrus and conception in high-producing Holstein cows. Anim. Prod. 1989, 49, 23-28.

Johnson RA, Wichern DW: Applied multivariate statistical analysis. Prentice-Hall, New Jersey 1982. $594 \mathrm{pp}$.

Kaplan LA: Urea. In: Pesce AJ, Kaplan LA (eds). Methods in Clinical Chemistry. The C.V. Mosby Company, Washington D.C. 1987, 22-26.

Kovacevic R, Krsmanovik L, Maric D, Perkucin R, Veselinovic $S$ : Investigation of hormone profiles in dairy cattle with a view to controlling fertility and increasing reproductive efficiency. In: Isotope aided studies on livestock productivity in Mediterranean and North African countries. Proceedings of the final research co-ordination meeting, Rabat 1987 , p. 255-273.

Lucy MC, Staples CR, Thatcher WW, Erickson PS, Cleale RM, Firkins JL, Clark JH, Murphy MR, Brodie BO: Influence of diet composition, drymatter intake, milk production and energy balance on time of post-partum ovulation and fertil- ity in dairy cows. Anim. Prod. 1992, 54, 323-331. Madsen J, Hvelplund T, Weisbjerg MR, Bertilsson J, Olsson I, Spröndly R, Harstad OM, Volden H, Tuori M, Varvikko T, Huhtanen P, Olafsson BL: The AAT/PBV protein evaluation system for ruminants. A revision. Norwegian J. Agric. Sci. 1995, Suppl. 19, 5-37.

Marion GB, Gier HT: Factors affecting bovine ovarian activity after parturition. J. Anim. Sci. 1968, 27, 1621-1626.

Mulder CM, Schouten JA, Popp-Snijeders: Non-esterified fatty acids. J. Clin. Chem. Biochem. 1983, 21, 823.

Nakamura T, Klopfenstein TJ, Owen FG, Britton RA, Grant RJ, Winowiski TS: Nonenzymatically browned soybean meal for lactating dairy cows. J. Dairy Sci. 1992, 75, 3519-3523.

Roche JF, Crowe MA, Boland MP: Postpartum anoestrus in dairy and beef cows. Anim. Reprod. Sci. 1992, 28, 371-378.

SAS Institute Inc., SAS/STAT Guide for Personal Computers, Version 6 Edition. Cary, NC: SAS Institute Inc., 1987. 1028 pp.

SAS Institute Inc., SAS Technical Report P-229, SAS/STAT Software: Changes and enhancements, Realease 6.07, Cary, NC: SAS Institute Inc., $1992.620 \mathrm{pp}$.

Savio JD, Boland MP, Hynes N, Roche JF: Resumption of follicular activity in the early post-partum period of dairy cows. J. Reprod. Fert. 1990, 88, 569-579.

Spicer LJ, Tucker WB, Adams GD: Relationships between energy balance, insulin-like growth factor- 1 and estrous behaviour during early lactation in dairy cows. Oklahoma Agricultural Experiment Station. Anim. Sci. Research Report 1990, MP-129, 338-345.

Staples CR, Thatcher WW, Clark JH: Relationship between ovarian activity and energy status during the early postpartum period of high producing dairy cows. J. Dairy Sci. 1990, 73, 938-947.

Stevenson JS, Britt JH: Relationships among luteinizing hormone, estradiol, progesterone, glucocorticoids, milk yield, body weight and postpartum ovarian activity in Holstein cows. J. Anim. Sci. 1979, 48, 570-577.

Vesanen M, Isomaa V, Bolton NJ, Alanko M, Vihko R: Bovine steroid hormone and SHBG concentrations postpartum and during the oestrous cycle. Acta Vet. Scand. 1990, 31, 459-469.

Villa-Godoy A, Hughes TL, Emery RS, Chapin LT, Fogwell RL: Association between energy balance 
and luteal function in lactating dairy cows. J. Dairy Sci. 1988, 71, 1063-1072.

Whitmore HL, Tyler WJ, Casida LE: Effects of early postpartum breeding in dairy cattle. J. Anim. Sci. 1974, 38, 339-346.

\section{Sammendrag}

Sammenheng mellom energibalanse og ovarieaktivitet $i$ en besetning med norske melkekyr.

Forsøket ble gjennomført med 34 førstekalvskyr som ble fồret med fri tilgang på grassurfôr og kraftfôr etter stadium i laktasjonen. Forsøket viste at antall dager fra kalving til første lutealfase ble signifikant redusert $(p<0.05)$ av en bedret energibalanse summert over laktasjonsuke 3-12. Effekten var betydelig da ett standardavviks økning av den summerte energibalansen relativt til middelverdien reduserte lengden med 12 dager. På samme måte førte bedret energibalanse til økt maksimal utskillelse av progesteron i første lutealfase, økt kumulativ utskillelse av progesteron mellom første og tredje progesterontopp og $ø \mathrm{kt}$ kumulativ progesteronsekresjon $\mathrm{i}$ første måned av drektigheten. For alle de 4 progesteronvariablene samsvarte regresjoner på NEFA og acetoacetat med resultatene for energibalanse.

(Received September 9, 1994: accepted August 20, 1995).

Reprints may be obtained from: K. Ljøkjel, Dep. of Animal Science, Agricultural University of Norway, P.O. Box 5025, N-1432 Ås, Norway. 